\title{
Günther Oestmann, The Astronomical Clock of Strasbourg Cathedral: Function and Significance. Trans. Bruce W. Irwin
}

\author{
Leiden and Boston: Brill, 2020. Hardback xvi, 348 pp. ISBN: 978-90-04- \\ 42346-6. \$179.00.
}

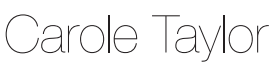

University of Wales Trinity Saint David

c.taylor@uwtsd.ac.uk

This latest volume in the Scientific Instruments and Collections book series (edited by Giorgio Strano) is a fascinating and detailed delineation of the history, construction and functioning of the second astronomical clock of Strasbourg Cathedral. As the back cover announces, "Strasbourg Cathedral's astronomical clock is one of the most famous and well-known astronomical clock monuments in the world. No other clock has been described and appreciated so often and in such a myriad of ways". Yet this book also provides new insight into the clock, in particular that it displays four ways of determining the astrological ascendant as described by Ptolemy and that it represents an original application, by its designer Conrad Dasypodius, of the architectural theory of Vitruvius.

Günther Oestmann is Professor of the History of Science at the Technical University of Berlin, with fields of research that range from the history of clocks and scientific instruments to the history of astronomy, history of astrology and mathematical geography, as well as maritime history and the history of navigation. He is also a professional clockmaker. The book is revised and updated from the original 1993 German edition, following Oestmann's 1992 PhD thesis on the Strasbourg clock, so it represents over four decades of careful research. We might say that the reader could not be in better hands. In this remarkable book, we see an accomplished historian's knowledge of the technical, astronomical and astrological elements of the clock and the fine attention to detail that we might expect from a professional clockmaker. Most exciting of all is Professor Oestmann's original and extensive contribution to our knowledge of the Strasbourg clock.

Oestmann divides the book into four parts. In Part 1, he describes the cathedral's original clock, built between 1352 and 1354 by an unknown clockmaker complete with astrolabe and a table outlining the astrological properties of the planets. Here the author's knowledge of the history and techniques of astrology and astronomy reveals itself in his 
discussion of its components; equally, his knowledge of the history of clockmaking and the known examples of the time provides helpful comparison and context. Known now as the "Three Kings Clock", Oestmann suggests a possible reason for inclusion of the Three Kings motif into the first clock as a secularisation of liturgical themes. This first model no longer survives, although Oestmann states that Dasypodius had studied it extensively. What does remain is its mechanical cock figure (now housed in the Strasbourg Musée des Arts Décoratifs, along with workings from the second clock). For this, Oestmann provides detailed illustration and analysis, and a discussion of its symbolic role in the liturgy of Holy Week. He then goes on to discuss a chiming tower clock built in the fourteenth century on the cathedral's southern tower platform, once again emphasising its literal and symbolic role as regulator of public life and religious worship.

Chapter 3 unfolds the plans for, and building of, a new astronomical clock to replace its medieval forerunner, this time to be situated on the wall opposite the original clock in the cathedral's southern transept. Oestmann is thorough (here as everywhere) in his detailed research of the city's plans for the replacement clock, the scholars and specialists who contributed to its making (in particular its original designer Christian Herlin), and his description of the clock's stone casing produced in the initial phase of building in 1547. At this time, the cathedral was under Protestant control, but an imperial decree the following year mandated the restoration of Catholic services, which in turn brought work on the new clock to a standstill until 1571, by which time the cathedral was again in the hands of Protestants. Chapter 4 then introduces those who brought this second astronomical clock into being: its aforementioned designer Conrad Dasypodius, master of the Strasbourg academy and a humanist scholar with a wide range of intellectual contacts that included Thomas Erastus and Johannes Kepler; Isaac and Josias Habrecht, who coordinated the technical execution; and Tobias Stimmer, who decorated the clock housing. Here the author includes much interesting biographical and personal detail on this cast of characters, including the tensions and conflicts between Dasypodius, on whom was placed responsibility for the entire project, and the Habrecht brothers, over which of them was the true author of the clock.

In Part 2, entitled "The Artistic Embellishments of the Second Clock", Oestmann resumes the fine detective work necessary to chart the progress of a clock whose successor (the second clock stopped working in the 1788 and was replaced the following century) has obscured aspects of its original form. He examines woodcuts and engravings made by Stimmer and others, reproducing them as illustrations to show the enormous complexity of the structure in its exterior aspect, and he guides us through a detailed description of its decoration. In its first tier are an ornate calendar plate, illustrated tables of eclipses (calculated by Dasypodius) and a procession of daily regents, a figure for each planet according to its classical association with a day of the week and its rulership of a zodiac sign as depicted in the Thema Mundi (Horoscope of the World). Several paintings on Biblical themes, described in some detail, complete this lower tier. Oestmann continues with a discussion of the central clock tower and its iconography (replete with astrological imagery and quaternity symbolism), followed by the tower for the weights with its depiction of Urania and of the three Fates (with the cockerel from the first clock 
sitting atop). All is described in detail, with a fine appreciation from the author for the astrological, mythical and philosophic symbolism of each component.

Finally, Oestmann turns his attention to Stimmer's portrait of Copernicus on the front of the weights tower, asking the question as to why Dasypodius included a portrait of Copernicus on the clock rather than of Ptolemy. He assesses the arguments made for the notion that Dasypodius was an early supporter of the heliocentric theory and concludes that Dasypodius did not support Copernican cosmology, being an adherent of the Ptolemaic system, but that he respected Copernicus for his astronomical expertise and made use of his discovery of the relationship between the sidereal and synodic periods for planetary orbits as the basis for designing the mechanism of the clock's astrolabe.

Part 3 takes us into the technical components of the second clock, beginning with a description of its mechanisms in Chapter 7. Oestmann then dives deeply into a discussion of the celestial globe, the astrolabe dial, the calendar disc and sundials.

We see a colour photograph of this magnificent celestial globe, $860 \mathrm{~mm}$ in diameter and set for the meridian of Strasbourg, based by Dasypodius on the crystal sphere of Archimedes and marked with the location of the supernova in Cassiopeia of 1572 (Tycho Brahe's "new star", the appearance of which fundamentally challenged Aristotle's position that the heavens were unchanging). A small copper pelican - a symbol of Christ's sacrifice - no longer extant but visible in Stimmer's woodcut, is described in beautiful cameo detail, and we learn about the calculations for the celestial globe's gear train and the Habrecht brothers' extraordinary craftsmanship in its execution.

The construction and workings of the astrolabe are then discussed, accompanied by illustrations which indicate clearly how it was put together. Here again, Oestmann shows not only his detailed technical knowledge but also his understanding of the astrological dimension, through his discussion of the Regiomontanus "house system" used for the astrolabe and through his explanatory detail with respect to the meanings of the 12 astrological houses with reference to works by authors who would have informed contemporary understanding, such as Ptolemy and Manilius. Finally, he turns his attention to the calendar disc and completes this section with a discussion of the sundials on the gable of the cathedral's southern transept.

Finally, in Part 4 ("Programmatic Meanings"), the author turns to Dasypodius' own programmatic explanations and description of the clock in his Heron Mechanicus, published in 1580. Oestmann explains that the book refers to Vitruvius and demonstrates Dasypodius' knowledge of the Roman author's architectural theory, and also shows that he was familiar with the technical writings of the Greek authors, in particular the NeoPlatonist Proclus. The Heron Mechanicus makes a distinction between a craftsman, who works by natural instinct, and the mechanicus logicus, whose work derives from a duty of prior philosophers and mathematicians; such a one must be erudite, well educated and possessed of intelligence and good judgment. Dasypodius states architecture as the queen of all the arts, under whose umbrella sit clockmaking and machine construction - for him, to be worthy of the name of architect, one must be a good theoretical mechanicus. His ideas, as Oestmann discusses, are drawn directly from Vitruvius' own views on the qualities needed by the architect, and on Vitruvius' architectural teachings 
generally, all of which are central to Dasypodius' approach to the design of the Strasbourg cathedral clock, albeit as a rather original interpretation of them. Central also are the differing roles of the architect and the craftsman, and the mutually interdependent relationship between them.

Oestmann judges that the Heron Mechanicus shows Dasypodius' knowledge of the technical literature from antiquity. Oestmann in particular cites the influence of the mathematician and engineer Hero of Alexandria, but amongst the list is also Ptolemy. In Chapter 12 then, we see the broad range of influences that shaped Dasypodius's approach to the clock's design. Finally, in Chapter 13, the author asks the question as to what motivated Dasypodius to create such a complex construction, with its numerous automata, workings and displays. Oestmann begins to answer this by first discussing Ptolemy and his great collected work on astrology, the Tetrabiblos. The discussion culminates in the author's discovery of Dasypodius' indication that the clock displays the methods for calculating the astrological ascendant described by Ptolemy, making the globe intrinsic to the design of the clock. Intrinsic too is the concept of time and the "moment" (the seed moment of birth, as outlined by Ptolemy), as is the notion of "symmetria", the symmetry shown in the relationship of all parts of the clock as one harmonious whole (Appendix I presents Dasypodius's commentary on Ptolemy's "De Parte Horoscopante" [Of the Degree of the Horoscopic Point], Tetrabiblos 3.2). With its astronomical, astrological and temporal components, the clock is thus truly the "monument to Time" described on the back cover of the book.

The book concludes with a discussion as to why such a magnificent and complex mechanism was installed in a cathedral. Here once again, the reader benefits from Oestmann's extensive knowledge of the historical context. He ends with a wider view of the clock as an abstract celestial model, positioned at the very heart of the city and constructed during a century which hailed a mechanised conception of the cosmos, but built also at the end of the era of monumental clocks and on the threshold of a century in which clocks became no more than instruments to measure linear time.

This is a penetrating account, meticulously researched and referenced, and full of technical and historical detail. It brims with the same conscientious erudition that Dasypodius so admired. That it is the summation of decades of scholarly study of the Strasbourg clock is clear on every page. It includes extensive footnotes and bibliography, and rich colour illustrations and technical drawings, and will surely be an indispensable companion for anyone interested in the history of clockmaking. It will also be of interest to the historian of astronomy, and indeed of astrology too. It adds significantly to our knowledge of this extraordinary clock as an instrument which encompasses the technical, the temporal, the celestial and the cosmological. 